\title{
Developing Private Equity Investment Fund to Promote Money Liquidity into Real Economy Effectively
}

\author{
Shuangqing Pan* \\ Quanzhou Normal University \\ Quanzhou City, Fujian Province, China, 362000 \\ email: shuangqingp@sina.com \\ *Corresponding author: Shuangqing Pan
}

\begin{abstract}
Private equity investment fund is an advanced financial tool which blends of capital, management and other elements, and it has promoted the development of the world economy. In Quanzhou city, it is effective in promoting liquidity into the real economy, create national pilot zone for comprehensive financial reform, promote the optimization and upgrading of the industrial structure, improve the level of corporate governance in private enterprises and other relevant. Government of Quanzhou city should strengthen the visibility of private equity investment fund related knowledge, strengthen policy support for developing private equity investment fund, and strengthen development of Quanzhou's local private equity investment fund.
\end{abstract}

Key Words: private equity investment; practical significance; recommendations

\section{INTRODUCTION}

Private equity investment fund, known as PE, it is generally understood as to private equity investments in non-listed companies or non-registered equity of listed company, this article is limited to exploring the situation of private equity investment in unlisted companies.

It is considered that the starting sign of private equity investment fund is the establishment of American research and development company (ARD) in 1946, the target of ARD is to provide long-term capital and expert management service for emerging enterprise and SMEs. Through providing long-term funds support and enterprise knowledge for entrepreneurs with innovation spirit and adventure spirit, to achieve effective distribution of various production elements, and to promote growth of innovation type enterprise. Private equity fund as a result of financial innovation and industry innovation, it widens financing channels for enterprises, and promotes the value discovering and value increasing of the invested companies. Meanwhile, it provided a high yield investment channel, and was recognized by an increasing number of investors. Private equity investment is playing an increasingly important role in the financial system, and it became the important financing instruments just next to bank loans and public offerings. At present, private equity received attention in many countries, and it contributed to the development of the world economy.

In China, the development of private equity investment also has more than 10 years' time. With the deepening understand of the concept of private equity investment in China, private equity investment is adopted by an increasing number of investors as a new type of investment instrument, making total new funds hit a record high for the year 2012, but starting from the end of 2011, because external environmental instability, IPO tightens and book return on investment fells, causing a lot of funds were not in place on time, affecting the total amount of funds raised.

The investigating report, "The impacts of private equity funds for China's economic and social" (2012) jointly issued by Bain Consulting Firm and the European Union Chamber of Commerce in China pointed out that, in just 10 years, status and influence of venture capital and private equity fund industry in China are soaring, they have been a driving force for the economic growth, employment creation, the promotion of innovation and nurturing entrepreneurs succeed[1].

Private equity investment fund helps to enhance corporate governance, to increase taxes, and to stimulate growth. The vast majority executive of company invested by private equity fund value the key management guidance provided by private equity fund firms. Private equity fund partners have played an important role in management and financial consultant, benefited from its investment company, they including: improving corporate governance, increasing the transparency of taxpayers, the establishment of a more open and transparent decision-making process, and redistribution of working capital to support expansion. Private equity fund firms may use their network of relationship to bring customers, suppliers and distribution channels for the invested company.

The companies invested by private equity fund are more willing to invest in research and development, adequate funding also makes this wish becomes a reality and ensure sustainable growth through innovation.

\section{THE PRACTICAL SIGNIFICANCE OF DEVELOPING PRIVATE EQUITY FUND IN QUANZHOU}

\section{A. It is the need to promote money liquidity into the real economy effectively}

After twenty or thirty years of rapid economic development in Quanzhou, and it accumulated a great deal of private capital, since most of the owners of capital do not have the professional capability of investment, and thus to some extent prevented the private capital into the real economy, causing excess money liquidity. Private equity investment fund gather private capital and their professional ability, and lead the excess liquidity into the real economy. By keeping private capital through the channels of private equity funds to discover and promote the rapid development of emerging 
industries, to promote the success of technology innovation and technology transfer, thereby to promote economic development. It can be said that the development of private equity investment fund is an important strategy to lead money liquidity into the real economy effectively.

\section{B. It is the need to create a national pilot zone for comprehensive reform of finance}

At present, the Quanzhou's financial system is dominated by commercial banks, and it is an indirect financing system, the financing demands of economic and social development reliance significantly on bank credit. The majority SMEs rely primarily on bank loans for alleviating fund shortages, but the small size of asset, operational risk, and lack of the necessary collateral in SMEs lead to the existing financial system which focus on cash flow and assets cannot meet the financing needs of SMEs.

To develop private equity investment fund can be considered as an important focal point during Quanzhou create national pilot zone for comprehensive financial reform. Private equity investment fund provide new financing channels for SMEs, and fill the vacancies of venture capital which traditional financing methods are not suitable. Private equity investment fund interest in the growth potential of the expected enterprise, and focuses on the company's future performance. The enterprises they selecting tend to be high risk, facing greater uncertainty, even there is no profitable businesses in the short term. Private equity investment fund suitable for enterprises in different stages of development, it can be from start-up phase of start-up enterprises to development phase of fast-growth companies that need of capital. Xia Bin (2001) argue that private equity investment fund is an important financial service system that a country's maturity market economy system there's going to have, its development conducive to fostering of institutional investors and stability of stock market[2]. Through the development of private equity investment fund for perfecting the system of investment and financing services in Quanzhou, reduce dependence on Bank of social capital, developing direct finance, broadening financial channels, and solve the contradiction of development of financial industry and finance needs of the community.

Former vice governor of People's Bank of China $\mathrm{Wu}$ Xiaoling believes that China's capital market does not lack financial factors that make up 99 Celsius degrees, but lack of the 1 Celsius degree that make water boiling, and the 1 Celsius degree is private equity investment fund[3].

Quanzhou is not lack of entrepreneurs be of a strategic vision, not lack of investors be of a risk spirit, not lack of resources that can be effective utilized, private equity investment fund is one of the financial instruments what we are lacking that may be able to combine various elements of economic development, to promote economy continue moving forward in Quanzhou.

\section{It is the need to promote the optimization and}

\section{upgrading of the industrial structure}

The work report of Quanzhou City Government in 2013 point out that Quanzhou city is to promote industrial development, commitment to transformation of innovation and breakthrough in optimizing the structure. Currently, Quanzhou city owns a number of brands, but the overall economic conditions is a large number of small and medium enterprises, wide industry distribution, low product quality, weak innovation capacity, and is a typical "low, small, scattered, weak" economic characteristics. Optimizing and upgrading the industrial structure means that the rise of the capital-intensive and technology-intensive industries, equipment of manufacturing industry will also face a large update, introduction of talent, and these are subject to the huge capital investments.

Scholtens and Wensveen (2000) considered that financial intermediation as represented by the private equity investment fund through financial support to high-tech enterprises, while higher gains in promoting scientific and technological innovation and improving productivity, they creating value for the society[4]. The characteristics of pursuit high return of private equity investment fund demand it necessarily put capital raised into industry with high technology, and technology advanced, and broad development prospects, just like new energy, and materials, and equipment manufacturing, and environmental industry, this in objectively pilot social capital into correct direction, promote industry structure optimization and upgrading. The managers of private equity investment fund, with rich of market operation and management experience, they can provide professional of value-added service for is investment enterprise, improve investment efficiency and benefits, improve resources efficiency. The advantages of funds and management of private equity investment fund make it a core driving force for the whole industry to integrate, accelerating industry consolidation, mergers and acquisitions, foster key industries and enterprises, thereby promoting structural adjustment and industrial upgrading.

\section{It is the need for raising the level of corporate}

\section{governance in private enterprises}

At present, it is a universal phenomenon of poor corporate governance standards in Quanzhou's private enterprises. From the family workshop along the way, in terms of company management philosophy, private enterprises employing mechanism, system construction, management tools, there is a big gap compares with the modern enterprise system, and these disadvantage factors constrain the enterprises growth bigger and stronger.

Private equity invest fund can promote the improvement of corporate governance[5]. A major difference between private equity financing and traditional debt financing is that the traditional debt financing of only capital, and private equity financing is not only access to finance but also improve the company's capital structure and corporate governance standards. After entering the invested companies, an effective board would be set up for oversight of management and communication with shareholders, 
introduce general board process, ensures corporate legal, compliance, and meet policy requirements. It will set up an audit, compensation and personnel committee, appoint a certain number of independent directors, the appointee are required sufficient experience and qualifications. The measures improve the level of corporate governance in private enterprises. The development trend of private equity investment funds is to enhance corporate value through corporate governance, and it is also the social value of private equity investment funds.

In short, Quanzhou city is going to transform the mode of economic development in "Twelve-Five" period, it must greatly promote the optimization and upgrading of industrial structure, speed up the cultivation of strategic emerging industries. Private equity investment fund as important capital strength to support entrepreneurship and innovation, it should and can make a more active contribution among areas such as promoting the progress of science and technology, promoting the optimization and upgrading of industrial structure, and innovation-driven economic development.

\section{FEASIBILITY OF QUANZHOU DEVELOPMENT}

\section{PRIVATE EQUITY INVESTMENT FUND}

\section{A. Having a good legal and policy environment}

\subsubsection{It has the preliminary conditions of National legal}

Begin with 2006, a series of legal regulations were amended and introduced, such as "The Law for Company", "The Law for Partnership Enterprise", "The Provisional Approach for Venture Investment Enterprise Management", "The Guidelines of Risk Management for Commercial Banks Merger Loan", "The Management Approach for Insurance Funds Using", "The Notification on Development of Promoting Equity Investment Enterprise", they have diversified the organization form of private equity investment fund, have widened sources channel and investment direction of capital, and have created a good legal environment for developing private equity investment fund. In addition, the solution of the problem of split share structure of capital market, launching of the entrepreneurial sector, and running of Tianjin Equity Exchange means a multi-level capital market system taking shape, they have created more convenient channels for private equity fund investment and exit.

3.1.2 The supports come from national and local policies

"The notice of 11 measures of Fujian provincial people's Government on financial services to the real economy development" introduced in May 2012, makes it clear to support Quanzhou city developing equity investment fund before the approval of the establishment of the national pilot zone for comprehensive reform of financial services to the real economy. The notice also proposed to increase the efficiency in the use of Channel Industry and venture capital funds at the provincial level, hold on to the formation of a strategic industries venture capital fund that scale no less than 1 billion Yuan of the total, and support the development of venture fund which central financial stake in.

In December 2012, finance reform plan of Quanzhou was approved, and it advance rapidly, the follow-up to "The plan of pilot zone for comprehensive reform of financial services to the real economy in Quanzhou city, Fujian province", and comprehensively promote the comprehensive reform of financial services to the real economy. It emphasized position of service real economy; follow the national macro orientation; responsive to industry trends; to the expectations of stability value added of social capital.

No doubt, the implementation of the above policy will bring rare historical opportunity for development of private equity investment fund in Quanzhou.

\section{B. Having a good economic base}

The GDP of Quanzhou City in 2012 is 472.65 billion Yuan, and it maintains No.1 position for 14 consecutive years in Fujian province. There are 130,000 private enterprises, the number of enterprises with billion Yuan of industrial output value reached 1704. By the end of October 15, 2012, listed companies totaled 76 in Quanzhou city, about 43 billion Yuan of financing, the highest in the number of listed companies in the province. At the same time, there are 2 companies are listing after the CRIC review made by the China Securities Regulatory Commission, 9 companies are waiting for review, 76 companies as provincial key reserve enterprise to be listing in 2012. About 25 industrial clusters were formed across the city, including textiles and garments, footwear and petroleum chemical industry which their annual output value exceeding 100 billion Yuan. Large economy scale and an active private economy, which brought huge financial needs, have laid a good foundation for the financial sector itself. The end of 2012, there are 31 banking institutions across the city, with deposits of 468.797 billion Yuan and loans of 372.422 billion Yuan. Sufficient private capital and SME resources provide good conditions for raise and investment of private equity invest fund.

\section{Having valuable experience for reference}

The private enterprises in Quanzhou experienced so many years of capital market, private equity investment fund are no longer strangers for them. They come from passive acceptance of private equity investment, reaching out to private equity investment, until the creation of Quanzhou's own private equity fund.

Many private enterprises of those already listed or preparation listed in Quanzhou, they tend to one round or several rounds of private equity financing before listing. These investment funds include Sequoia Capital, the Carlyle Group, CCB International Investment, Shenzhen Innovation Investment, Lenovo Investment and other well-known figure of private equity investment fund. The private equity financing not only addresses the issue of financing of these enterprises, but also improve the enterprises ' awareness of private equity investment funds.

In particular, Beijing, Shanghai, Tianjin and other places across the country also accumulated some valuable experience for reference in the development process of $\mathrm{PE}$ in recent years. 


\section{CONCLUSION}

\section{A. Strengthening knowledge of private equity investment} fund related publicity

Relevant government departments should strengthen the visibility of private equity investment fund related knowledge, active use a variety of media including of Web site, newspapers, forums, investment fairs, tell success stories about actively promoted through the development of private equity investment funds for increasing social investment, promoting the optimization and upgrading of the industry, accelerating the development of social, to enhance staff awareness of the economic and social benefits of private equity investment funds. Let more investors and the enterprise need to finance recognize private equity investment fund as an innovative financing tool it plays an important role in smooth investment channels and address enterprise financing.

\section{B. Strengthening policy support for private equity fund development}

Learn from normative documents launched in provinces and cities to promote development of local private equity investment fund, they offered various preferential measures such as tax benefits to talent and guidance fund. Preferential fiscal and tax policies as well as various guidance funds are impetus which attracting private equity investment funds settled down and promoting the development of private equity investment funds. Quanzhou can refer to their practices and introduce policies and regulations in favour of development of Quanzhou's private equity investment funds.

\section{Enhancing the development of domestic private} equity investment fund of Quanzhou city

Private equity investment fund has the feature of localization requirements. Firstly, local private equity investment fund can get better avoid problems such as adverse selection and moral hazard due to asymmetric information. China social credit system is not perfect, local private equity investment funds have a natural advantage in dealing with asymmetric information. After all, the survival and development conditions of the local business are relatively understood. Secondly, the local private equity investment fund helps communication between two sides. It is necessary for adequate communication with invested companies before the investment, the communication results directly affecting the investment or not. The same social and cultural background has a positive impact on communication effectiveness, but also beneficial to investors and invested companies to establish long-term cooperative relations.

\section{ACKNOWLEDGEMENT}

This research was financially supported by Fujian Higher Education service on the project of Western Strait Construction (B054).

\section{REFERENCES}

[1] The influence on China's economic and social of private equity funds-2012 research. http://www.docin.com/p-490416151.html/.

[2] Xia Bin. Report of China's "private funds" [J], Financial Research, 2001, No.08.

[3] Wu Xiaoling. China's capital markets lack of 1 degree Celsius which makes water boiling. [EB/OL]. (2006).http://www.sina.com.cn/.

[4] Scholtens, Bert\&Van Wensveen, Dick.A critique on the theory of financial intermediation[J], Journal of Banking and Finance, 2000, (24).

[5] Private Equity Council. Driving Growth: How Private Equity Investments Strength American Companies[EB/OL].(2007).http://www.Private Equity Council.org/. 